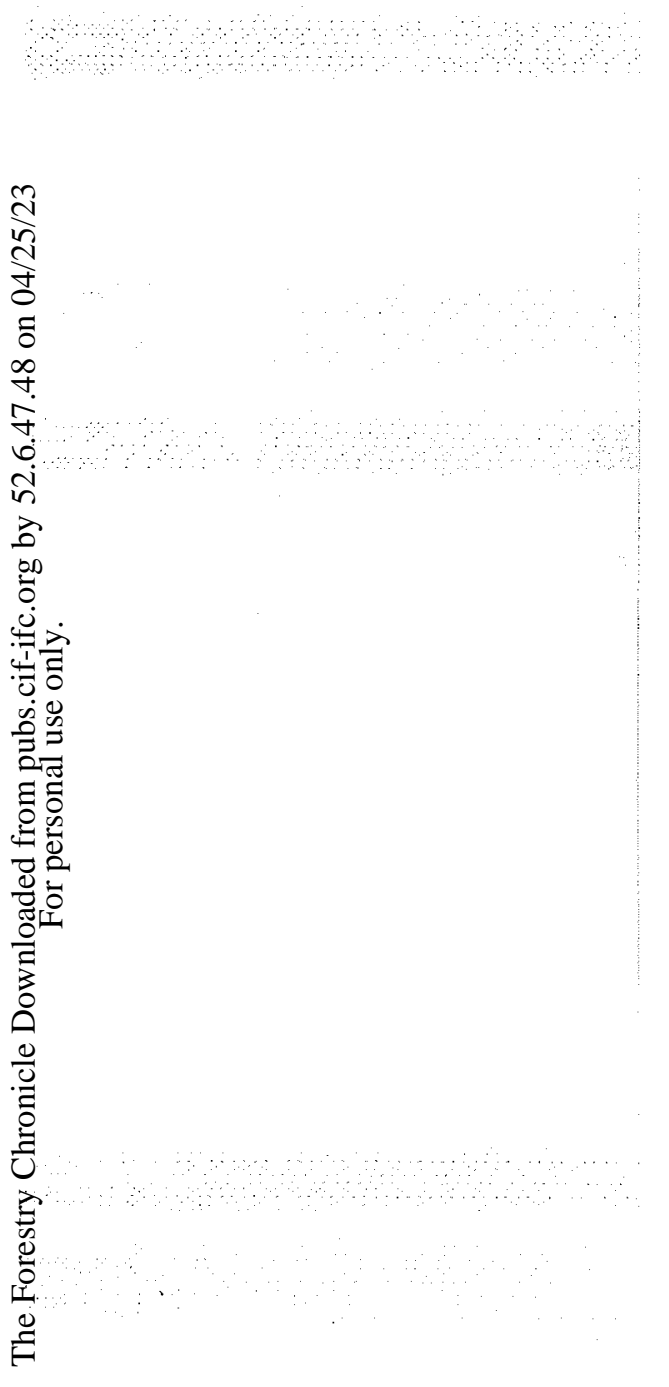

Society of American Foresters
Awards Medals for Distinguished Service to Forestry

E. L. Demmon of Asheville, North Carolina, president of the Society of American Foresters, presented two of the forestry profession's highest awards at the Society's dinner, held in connection with its 54th annual meeting, in the Schroeder Hotel, Milwaukee, Wisconsin, on October 27.

To William L. Hall of Hot Springs, Arkansas, was presented the Gifford Pinchot medal, named for the late first chief of the U.S. Forest Service, founder and first president of the Society of American Foresters, and one of America's foremost conservationists. Mr. Hall was a cofounder with Mr. Pinchot of the Society, and is the owner and manager of extensive producing timberlands in Arkansas. Eighty-one years of age, he is the oldest professional forester in America in active practice.

To Tom Gill of Washington, D.C. was presented the Sir William Schlich Memorial Medal, named for one of the most eminent foresters of the Englishspeaking world. Sir William (1840-1925) was inspector general of forests in India, professor of forestry at Oxford University, and author of the Manual of Forestry, an early monumental work on forest management.

Dr. Gill, executive director of the Charles Lathrop Pack Forestry Foundation, was awarded the medal for distinguished service to international forestry. He has been a forestry consultant to several governments in Central America and the Orient, and is a special forestry adviser to the Food and Agriculture Organization of the United Nations.

\title{
Forest Science Journal to Appear
}

The first issue of Farest Science, an International Journal of Research and Technical Progress in Forestry, will appear in March, 1955, according to the chairman of its board of editors, Stephen H. Spurr, University of Michigan professor of silviculture.

A co-operative venture of the Society of American Foresters and other forest research and educational organizations, the quarterly journal will print articles on any forestry subject, but mainly those of interest to research, teaching and administrative personnel. Special preference will be given to articles discussing the results of original research.

A grant of $\$ 2,000$ from the Horace H. Rackham Fund of the University of Michigan is making possible the initial publication of the journal, which will be under control of a three-man board of editors: Henry Clepper, executive secretary of the Society of American Foresters; V. L. Harper, assistant chief (Forest Research) Forest Service, U. S. Department of Agriculture; and Professor Spurr.

The pre-appearance subscription price is $\$ 6.00$ per year. For further information write to: Prof. Stephen H. Spurr, School of Natural Resources, University of Michigan, Ann Arbor.

Western Forestry and Conservation Association Meets

About 20 British Columbia foresters attended the 45 th annual meeting of the Western Forestry and Conservation Association in San Francisco from De- 